\title{
Centralização política e desenvolvimento financeiro no Brasil império (1853-66)*
}

\section{Political centralization and financial development in Imperial Brazil (1853-66)}

\author{
THIAGO FONTELAS ROSADO GAMBI \\ Professor do Instituto de Ciências Sociais Aplicadas \\ Universidade Federal de Alfenas (UNIFAL) \\ Av. Alfredo Braga de Carvalho, 303 - Parque Industrial JK \\ CEP 37062-440 - Varginha - MG \\ thiago.gambi@terra.com.br
}

RESUMO Em meados do século XIX, no Brasil, estava em marcha um projeto conservador que visava a centralização política na capital e se manifestava em diversos planos: jurídico, militar, social, cultural e econômico. Neste último plano, o projeto se manifestava na proposta de centralização do controle da oferta monetária nas mãos de um banco emissor. Argumenta-se que a política econômica dos conservadores emanava da Corte (centro) e subordinava as províncias (periferia). Seu resultado foi a obstaculização do desenvolvimento financeiro tanto no centro como na periferia.

Palavras-chave centralização política, finanças, Império

ABSTRACT In the middle of the $19^{\text {th }}$ century, in Brazil, there was in progress a conservative project that aimed political centralization in the capital and

* Artigo recebido em: 20/06/2011. Aprovado em: 01/12/2011. 
expressed itself in several plans: legal, military, social, cultural and economical. In this last plan, the proposal of centralization of the control of the monetary offer in a emission bank. This text argues that the economic policies carried out by the conservatives emanated from the Corte (centre) and subordinated the provinces (periphery) and his result leads to the obstaculization of the financial development both in the centre and in the periphery.

Keywords political centralization, finance, Empire

\section{Introdução}

No Brasil de meados do século XIX estava em marcha o projeto de construção do Estado Nacional levado a cabo por políticos conservadores. Era um projeto que visava à centralização política na capital do império e se manifestava em diversos planos: jurídico, militar, social, cultural e econômico. Neste último plano, o projeto se expressava por meio da proposta de centralização do controle da oferta monetária nas mãos de uma instituição financeira privada, mas influenciada fortemente pelo governo. Para que esta proposta se concretizasse, o mesmo governo promoveu a criação de um grande banco privado a quem caberia a execução de uma política econômica que mirava, ainda que com algumas adaptações, a adesão ao padrão-ouro. A moeda forte e lastreada em metal seria requisito de um país que se pretendia ordenado e civilizado. Era esse o objetivo final do projeto conservador.

Ligado ao governo, esse banco contaria com o monopólio de emissão de notas bancárias para que, a partir da capital, pudesse controlar a oferta monetária de todo o país e, assim, sanear seu meio circulante. A escassez de meio circulante para realização de transações comerciais e de crédito era um problema crônico da economia brasileira na época. Para amenizar o problema, as praças de comércio mais importantes contavam com bancos emissores privados. No entanto, a concretização do novo banco na capital, em 1853, decretou o fim da pluralidade de emissão no país. Este novo banco era o segundo Banco do Brasil ${ }^{1}$ e tinha o privilégio do monopólio de emissão, mais um passo no sentido da centralização do poder político, inserida no projeto conservador. Para preencher o vácuo monetário deixado pelo monopólio, os bancos emissores provinciais tornaram-se caixas filiais do novo banco. A passagem

Chamamos de segundo Banco do Brasil o banco criado por iniciativa de Joaquim José Rodrigues Torres, em 1853. O primeiro fora criado em 1808 e se extinguiu em 1829. Entre 1851 e 1853, também funcionou um banco chamado Banco do Brasil, do qual Irineu Evangelista de Souza era sócio. No entanto, não o consideramos como o segundo Banco do Brasil por ter sido uma instituição eminentemente privada, sem relação formal com o governo imperial. 
da pluralidade para o monopólio de emissão traria conseqüências políticas e econômicas para as províncias mais distantes da capital, pois passariam a depender ainda mais das decisões tomadas pelo poder central.

Essa ação parece corroborar a interpretação de José Murilo de Carvalho segundo a qual a elite política conduzia um Estado relativamente autônomo frente a uma sociedade fragilizada. ${ }^{2}$ É verdade que a política econômica saquarema e a criação do Banco do Brasil estavam ligadas a membros da elite política, notadamente Rodrigues Torres. No entanto, vale lembrar que muitos membros dessa elite também faziam parte do círculo mercantil-escravista - 0 próprio Rodrigues Torres é um exemplo -, o que lança dúvidas sobre a relativa autonomia do Estado e a fragilidade da sociedade. A força da ação centralizadora exercida pelos saquaremas no campo econômico também não nega a atuação das elites dominantes locais, como observa Míriam Dolhnikoff, ${ }^{3}$ e os embates políticos no legislativo. Contudo, o que restou desses embates de 1853 a 1866, período em que o Banco do Brasil funcionou como emissor, é uma política econômica muito próxima daquela defendida pelos saquaremas, tendente à centralização do controle da oferta de moeda. Rodrigues Torres, o Banco do Brasil e a política econômica do período nos remetem à interpretação de llmar Mattos, para quem os saquaremas imprimiram uma direção política e moral ao império. No campo econômico, a direção política se expressaria no monopólio de emissão do Banco do Brasil, centralizando o controle da oferta de moeda na Corte. Já a direção moral se refletiria na rejeição da moeda fiduciária, um vício, e na busca da moeda forte, uma virtude, condição para a construção de um império civilizado nos trópicos.

A fim de explorar melhor as implicações do projeto saquarema e da instauração do monopólio de emissão, via Banco do Brasil, para o desenvolvimento financeiro do centro (capital) e da periferia (províncias), este texto discute, primeiro, o projeto conservador e os debates políticos em torno da pluralidade e monopólio de emissão para, em seguida, avançar na análise de dados do banco e de suas caixas filiais. Argumenta-se que a política econômica levada a cabo pelos conservadores, de fato, emanava do centro e subordinava a periferia, coerente com o projeto de centralização política. Contudo, seu

2 CARVALHO, José Murilo. A construção da ordem: teatro de sombras. Rio de Janeiro: Civilização Brasileira, 2008. André Villela fala em autonomia do Estado em relação aos fazendeiros para formular a política econômica. Cf. VILLELA, André Arruda. The Political Economy of money and banking in Imperial Brazil 1850-1870. London, London School of Economics and Political Science, 1999. (Philosophy, Thesis of Degree of Doctor).

3 DOLHNIKOFF, Miriam. O pacto imperial: origens do federalismo no Brasil. Rio de Janeiro: Globo, 2005; DOLHNIKOFF, Miriam; MAIA, Francisleide; SAEZ, Hernan Lara; SALES, Pedro Paulo Moreira; GREGÓRIO, Vitor Marcos. Representação política no Império: crítica à idéia do falseamento institucional. In: LAVALLE, Adrian Gurza. (org.) O horizonte da politica: questões emergentes e agendas de pesquisa. São Paulo: Unesp, CEBRAP, CEM, 2012, p. 97-141. 
resultado foi a obstaculização do desenvolvimento financeiro do país tanto no centro como na periferia.

\section{O projeto político conservador}

No Brasil imperial, 'saquarema' era a designação mais geral dos membros do partido conservador. Os dirigentes saquaremas, segundo Mattos, ${ }^{4}$ eram os que exerciam, por meio do Estado e de suas ações, uma direção intelectual e moral que se refletia num projeto político hegemônico balizado pelos princípios de ordem e civilização. A direção saquarema personificava-se em senadores, magistrados, ministros e conselheiros, isto é, na alta burocracia imperial; nos grandes proprietários rurais de diversas províncias do império, que se guiavam pelo brilho emanado da Coroa; nos grandes negociantes; e em profissionais liberais que defendiam os princípios de ordem e civilização e sua difusão. Ao levar a cabo seu projeto de construção do Estado imperial, os saquaremas promoveram, simultaneamente, a constituição de uma classe senhorial que intervinha, consciente e deliberadamente, naquela construção.

Ocorre que, no interior da classe senhorial, os interesses econômicos e políticos eram heterogêneos e, por isso, seus representantes disputavam espaço no Estado imperial. A tacada política dos saquaremas foi deslocar de si mesmos para a figura do imperador, para a Coroa, o centro da ordem e da defesa dos interesses dessas frações de classe, favorecendo a aliança entre o rei e os barões. ${ }^{5}$ Nas contendas políticas remanescentes, a figura do imperador deveria pairar sobre as diferenças partidárias. Não se tratava assim de interesses de conservadores ou liberais, de saquaremas ou luzias, mas do interesse do império brasileiro. Os saquaremas impunham sua direção tendo o imperador como escudo. Era como se o projeto político desse grupo fosse a voz da razão impondo-se em meio ao torvelinho das paixões políticas, que eram creditadas na conta da oposição liberal.

Para os saquaremas, o imperador devia reinar, governar e administrar, sendo o poder moderador a instância a partir da qual se organizava a política do império. Dessa maneira, inteligentemente neutralizadas as forças de oposição ao projeto conservador, proprietários rurais escravistas e negociantes foram incorporados a tal projeto e seus negócios expandiam-se protegidos pelo Estado imperial. Com a famosa trindade saquarema ${ }^{6}$ no poder, contemplavam-se nele, sobretudo, os interesses de grandes proprietários

4 MATTOS, Ilmar Rohloff de. O tempo Saquarema: a formação do Estado imperial. São Paulo: Hucitec, 2004. p.3.

5 MATTOS, Ilmar Rohloff de. O tempo saquarema, p.179; CARVALHO, José Murilo. A construção da ordem, p.249-260.

6 A trindade saquarema era formada por Eusébio de Queirós, Rodrigues Torres e Paulino José Soares de Sousa. 
das lavouras cafeeiras do vale do Paraíba que formavam a base da economia exportadora e estavam em expansão e dos grandes negociantes que detinham o capital e forneciam crédito para financiar tais lavouras e sua expansão, sustentando o projeto político saquarema. Embora houvesse grandes proprietários da Bahia e Pernambuco a sustentar o projeto, a base do apoio conservador estava na Corte. ${ }^{7}$

A direção intelectual e moral impressa no projeto expressava-se na defesa da soberania, da ordem, da monarquia e da escravidão em oposição à representação política, à vontade nacional, à democracia e à liberdade. ${ }^{8}$ Por isso não surpreende a acusação da oposição liberal ao despotismo saquarema. O rumo daquela direção implicava na centralização do poder político na Corte, aproximando-se mais do modelo de Estado francês, do que dos modelos inglês ou estadunidense. ${ }^{9}$ Em termos econômicos, o rumo da direção saquarema implicava na manutenção da economia mercantil escravista, isto é, sua preocupação precípua era fazer com que essa economia funcionasse para o bem da ordem e do império. Significa dizer que o projeto saquarema deveria resolver dois problemas crônicos da economia brasileira, a saber, a estabilidade do valor do meio circulante e a escassez de numerário e de crédito nas praças. Com a estabilidade do valor do meio circulante e, conseqüentemente, com a estabilidade do câmbio, ganhariam os proprietários rurais ligados ao comércio de exportação e os próprios exportadores e importadores, uma vez que tal estabilidade diminuía o risco cambial envolvido nas transações de comércio exterior. 0 Estado também se beneficiaria com ela ao honrar compromissos externos em moeda estrangeira em condições favoráveis e ao construir uma reputação que poderia ajudá-lo em caso de necessidades futuras de crédito. Com a ampliação da oferta de numerário e crédito, ganharia a classe senhorial como um todo, abrindo espaço inclusive para o surgimento de manufaturas. Finalmente, a conquista de uma moeda forte representaria a concretização parcial do projeto saquarema e abriria para o império uma das portas de entrada para o seleto grupo das nações civilizadas.

Entretanto, o governo sozinho não daria conta de, ao mesmo tempo, lastrear a emissão de notas em metal, tal como se apresentava a miragem do padrão-ouro, e garantir a oferta necessária de numerário e crédito ao comércio. Estabilidade do valor do meio circulante e ampliação da oferta de crédito revelavam-se objetivos conflitantes. 0 governo saquarema, apesar do

7 GUIMARÃES, Carlos Gabriel. Bancos, economia e poder no segundo reinado: o caso da sociedade bancária Mauá, Macgregor \& Companhia (1854-1866). São Paulo, USP, 1997. (História Econômica, Tese de doutorado).

8 MATTOS, Ilmar Rohloff de. O tempo saquarema, p.198.

9 MATTOS, Ilmar Rohloff de. O tempo saquarema, p.152-164; CARVALHO, José Murilo. A construção da ordem, p.138. 
discurso do crédito, não escondia o privilégio do controle monetário e a opção pela miragem do padrão-ouro. Entrava em cena a necessidade de se criar um grande banco que o auxiliasse nessa tarefa.

Em suma, a direção saquarema buscava tocar o projeto de construção de um Estado que pudesse trazer ordem e civilização ao império brasileiro. No campo jurídico-político e militar, esse projeto significava centralização do poder na Corte e racionalização da ação estatal por meio de uma burocracia que seguia as diretrizes do imperador para o bem do império. No campo sócio-cultural, significava reforçar a defesa dos princípios de ordem e civilização, e a coesão da classe senhorial em torno desses princípios. No campo econômico, significava centralizar o controle da oferta monetária nas mãos de uma instituição financeira privada, mas influenciada fortemente pelo governo, a fim de ordenar o meio circulante, isto é, assegurar a manutenção do valor do mil-réis, e ampliar a oferta de crédito. A luta por uma moeda forte cumpriria funções imanentes e transcendentes nesse quadro. Além de favorecer o Estado em relação aos seus compromissos financeiros internacionais, a moeda forte serviria para reforçar a posição política dos saquaremas no interior do Estado e garantir identidade a um império que se pretendia civilizado. A criação de um banco para auxiliar o Estado nessa tarefa caía como luva no projeto conservador.

A conjuntura econômica de 1852, que combinava concorrência entre os bancos emissores do Rio de Janeiro e superávits fiscal e comercial, estimularia Rodrigues Torres a apresentar sua proposta de criar um grande banco nacional com ramificação nas províncias e monopólio da emissão de notas no país. Tal como seria proposto, o banco centralizaria o controle da oferta monetária, encaixando-se, dessa maneira, no plano conservador como braço financeiro do projeto de construção do Estado imperial, com vistas à manutenção da ordem e difusão de uma civilização. Como diriam Bárbara Levy e Ana Maria Ribeiro de Andrade, “o segundo Banco do Brasil, aparelhado com o monopólio de emissão, correspondeu ao nível da política monetária à unificação que se processava no plano político-militar". ${ }^{10} 0$ monopólio da emissão de notas bancárias seria a face da centralização política no campo financeiro e, assim, apontava disputas entre centro (capital) e periferia (províncias). Em 1852, a conjuntura econômica favorável e a posição política privilegiada dos conservadores ajudaram na implementação do que viria a ser o segundo Banco do Brasil, mas a nova instituição financeira só seria estabelecida depois de muitos debates parlamentares a respeito da questão.

10 LEVY, Maria Bárbara e ANDRADE, Ana Maria Ribeiro de. Fundamentos do sistema bancário no Brasil: 18341860. Estudos Econômicos, São Paulo, v.15, n. especial, p.19, 1985. 


\section{O debate parlamentar sobre o monopólio de emissão}

O debate sobre o monopólio de emissão no parlamento trazia implícita a questão da moeda, do crédito, da centralização e da descentralização do poder político. 0 que estava explícito no debate eram as doutrinas papelista e metalista. A controvérsia entre papelistas e metalistas já foi bem estudada pela historiografia brasileira. ${ }^{11}$ Por isso, não cabe aqui recuperar todo o debate sobre as teorias monetárias em voga no estrangeiro e a realidade econômica brasileira. Cabe, no entanto, situar no debate a discussão específica sobre a pertinência de se criar um banco que auxiliasse o Estado a sanear o meio circulante do país. Alguns dos pressupostos teóricos que estariam por trás da criação do segundo Banco do Brasil surgiram exatamente a partir desse debate travado entre parlamentares nas décadas de 1840 e 1850, já no contexto da influência política saquarema.

Quanto à questão da emissão especificamente, o grupo papelista defendia a pluralidade de instituições emissoras privadas não só por uma questão de liberdade - o livre mercado e a livre iniciativa deviam vigorar apesar da escravidão -, como por uma questão de geografia, isto é, a dificuldade de capilarização das notas de um banco emissor centralizado num ponto específico do vasto território brasileiro. Somente a pluralidade seria suficiente para garantir o giro dos negócios e a efetivação das transações. Eram os homens do crédito. Já o grupo metalista, que pretendia sustentar a paridade fixada em 1846, defendia a criação de uma única instituição emissora sob tutela do Estado, que se encarregaria de regular o volume de emissões de acordo com a necessidade da economia. A provisão de liquidez ao mercado ficaria subordinada à manutenção do valor da moeda. Teoricamente, eram os homens da moeda. Mas só teoricamente, pois a realidade da economia brasileira não cedia espaço para o idealismo metalista. O lastro das emissões de notas bancárias por aqui também seria formado por papel-moeda estatal.

11 Para citar apenas alguns autores, SAES, Flávio Azevedo Marques de. Crédito e bancos no desenvolvimento da economia paulista 1850-1930. São Paulo: IPE/USP, 1986; ANDRADE, Ana Maria Ribeiro de. 1864: a controvérsia entre papelistas e metalistas. Rio de Janeiro, UFRJ, 1987. (História, Dissertação de mestrado); GREMAUD, Amaury Patrick. Das controvérsias teóricas à política econômica: pensamento econômico e economia brasileira no Segundo Império e na Primeira República (1840-1930). São Paulo, USP, 1997.(Economia, Tese de doutorado); TEIXEIRA, Arilda Magna Campanharo. Determinantes e armadilhas da política monetária brasileira no II Império. Rio de Janeiro, UFF, 1991. (Economia, Dissertação de mestrado); VILLELA, André Arruda. The political economy of money and banking in Imperial Brazil 1850-1870. E mais recentemente FONSECA, Pedro Cezar Dutra. A controvérsia entre papelismo e metalismo e a gênese do desenvolvimentismo no Brasil. XXXVI Encontro Nacional de Economia da ANPEC, Salvador, CD-ROM, 2008; SÁEZ, Hernán Enrique Lara. Nas asas de Dédalo: um estudo sobre o meio circulante no Brasil entre os anos de 1840 a 1853. São Paulo, USP, 2008. (História Econômica, Dissertação de mestrado). 
Apesar de todo o problema que implica o metalismo aplicado a uma economia com escassez de metal, a saber, a conseqüente escassez de moeda e crédito, permaneceria no império a busca pelo padrão-ouro, ainda que como miragem. A política de sustentação de uma moeda forte era tida como virtuosa por parcela importante dos conservadores e, além disso, casava-se, de maneira mais específica, com os compromissos externos assumidos pelo governo imperial, inclusive via construção de confiança nos credores estrangeiros, sobretudo ingleses, e, de maneira mais geral, com os planos civilizatórios desse grupo político.

Para mostrar como os bancos apareciam no debate, e sobretudo possíveis referências que aparecerão mais tarde na criação do segundo Banco do Brasil, selecionamos falas dos dois políticos que talvez tenham sido os mais influentes em assuntos financeiros e bancários em sua época: Souza Franco e Rodrigues Torres. Essas falas tiveram lugar nas sessões da câmara em que se deu a extensa discussão sobre a provincialização do meio circulante ${ }^{12}$ e em trabalhos impressos dos dois contendores, a saber, o opúsculo Os bancos do Brasil, do primeiro, e os relatórios do ministério da fazenda, do segundo.

De maneira geral, tanto Souza Franco como Rodrigues Torres atrelavam uma reforma monetária à reforma do sistema bancário, mas havia discordância quanto ao momento de se criar um banco ou bancos de emissão para auxiliar o governo no controle da oferta de crédito e moeda. Nessa ordem para Souza Franco e na ordem inversa para Rodrigues Torres. Para o deputado paraense, o governo devia criar imediatamente, isto é, por volta de 1850 , época em que ocorreu a discussão sobre essa matéria, um banco de emissão para que fosse garantido o crédito necessário ao comércio e, ao mesmo tempo, para que fosse valorizado o meio circulante por meio da substituição das notas do Tesouro por notas do banco.

$\mathrm{Na}$ apreciação do projeto de provincialização do meio circulante proposto pelo então ministro da fazenda Rodrigues Torres na câmara, a questão dos bancos aparecia freqüentemente. Na sessão do dia 8 de março, Souza Franco criticou o ministro, que estava presente à sessão, por sua restrição à criação de bancos emissores. Além de referir-se ao caso bem sucedido do Banco da Bahia, fundado em 1845, utilizou exemplos europeus em sua crítica, como os

12 Essa discussão ocorreu nas sessões de 7 e 8 de março e 25 e 26 de abril de 1850. Depois de longas discussões, a provincialização do meio circulante defendida por Rodrigues Torres e criticada por Souza Franco acabou aprovada como lei 552, de 31 de maio de 1850. No entanto, a provincialização não chegou a ser levada a cabo pelo governo. Cf. MINISTÉRIO DA FAZENDA. Proposta e relatorio apresentados á Assembléa Geral Legislativa na Terceira Sessão da Oitava Legislatura do anno de 1850 pelo Ministro e Secretario d'Estado dos Negocios da Fazenda Joaquim José Rodrigues Torres. Rio de Janeiro: Typ. Nacional, 1851. p.35. 
bancos da Inglaterra, Escócia e Irlanda. ${ }^{13}$ E como já havia proposto anteriormente, inclusive em seu projeto de reforma bancária de 1848, o deputado voltou à carga na sessão de 25 de abril defendendo a criação imediata de bancos de emissão, mesmo que lastreada em títulos públicos. Não seria preciso esperar a redução do papel-moeda em circulação nem uma composição ideal, entre metal e papel, do estoque de moeda para que tais bancos fossem criados, como mostravam os casos da Inglaterra e dos Estados Unidos. A criação de bancos tanto na Corte como nas províncias era vista por Souza Franco como uma alternativa urgente para sanar as deficiências de meio circulante e crédito enfrentadas pela economia mercantil. ${ }^{14}$

No entanto, a política econômica de Rodrigues Torres visava estabilizar o valor do mil-réis e, em sua perspectiva, para que isso ocorresse seria preciso enxugar o meio circulante, isto é, reduzir o volume de papel-moeda em circulação, seguindo nesse aspecto a teoria quantitativa da moeda. Para ele, ainda não era o momento de se criar bancos de emissão no Brasil, embora reconhecesse sua importância para o comércio e a indústria, pois tais bancos poderiam elevar o volume de papel-moeda em circulação. Vale notar que o problema do ministro era com bancos de emissão e não com bancos de depósitos e descontos, pois em sua concepção estes não criavam moeda.

Aliás, os metalistas de maneira geral não viam os bancos de depósitos e descontos como criadores de moeda, o que se pode comprovar com a autorização dada pelo ministro Torres Homem, em 1859, para a criação de vários desses bancos num momento em que era claro o objetivo de redução do volume do meio circulante. Em resposta a Souza Franco, Rodrigues Torres reconhecia a utilidade dos bancos emissores, mas não naquele momento. ${ }^{15}$

Quem lesse apenas essas palavras proferidas pelo ministro no parlamento não poderia imaginar que três anos depois ele seria o mentor da criação de um banco emissor justamente para substituir o papel-moeda do governo por suas notas. No entanto, não se tratava de uma mudança de posição em relação ao assunto como o próprio autor deste texto apontara num artigo escrito ainda com a pesquisa em andamento, nem mesmo de uma mudança parcial, como apontou Villela. Como bem observa Pacheco, embora criticasse os bancos de emissão àquela altura, ele deixara uma porta aberta para a criação de tais bancos ao atrelá-la à conjuntura. ${ }^{16}$

13 Cf. BRASIL. Assembléia Geral Legislativa. Anais da Câmara dos Deputados. Rio de Janeiro, p.105. Sessão de 8 de março de 1850.

14 Cf. BRASIL. Assembléia Geral Legislativa. Anais da Câmara dos Deputados. Rio de Janeiro, p.481. Sessão de 25 de abril de 1850.

15 Cf. BRASIL. Assembléia Geral Legislativa. Anais da Câmara dos Deputados. Rio de Janeiro, p.100. Sessão de 8 de março de 1850.

16 GAMBI, Thiago F.R. Considerações sobre a primeira fusão de bancos no Brasil. Leituras de economia política, 
É fato que ele não concordava com a criação imediata de bancos de emissão, mas vislumbrava um momento em que ela poderia se tornar útil para o país e tal momento chegaria quando a emissão dos bancos pudesse ser lastreada em metais. Todo o problema do ministro aqui era o medo de que as notas dos bancos emissores entrassem em circulação como papel-moeda, o que de fato acontecia, e contribuíssem para desvalorizar o mil-réis. Em sua visão, ao promover a desvalorização da moeda, a concorrência entre notas de bancos e notas do governo seria prejudicial para a economia do país.

O que fará então o ministro em 1853? Chegado o momento, por meio da criação de um banco com monopólio de emissão, promoverá justamente a troca das notas do Tesouro por notas do novo banco, ou seja, depois de algum tempo, teoricamente, o meio circulante nacional deveria ser composto exclusivamente por notas do Banco do Brasil conversíveis em metal ou papel-moeda emitido pelo Tesouro. Na nova instituição, permaneceriam a unidade de emissão e o ideal do lastro metálico, conforme sempre defendeu. Naquela altura, a conjuntura mudou, daí o momento de se criar um banco para auxiliar o governo na manutenção do valor da moeda, mas as idéias de Rodrigues Torres permaneceram as mesmas.

Voltando ao debate, Rodrigues Torres contra-argumentava que os exemplos estrangeiros apresentados por Souza Franco não seriam adequados à realidade brasileira. Na concepção do ministro, não era possível, transplantar os casos da Europa e da América do Norte para o Brasil sem mais, pois a quantidade de moeda em circulação dependia das condições da economia de cada país. ${ }^{17} \mathrm{O}$ discurso conservador no campo financeiro ia se fortalecendo e a figura do monopólio ia se definindo no horizonte.

Na sessão de 8 de março, num discurso alinhado ao da escola monetária, o ministro advertia seu adversário dizendo que não se podia confundir meio circulante e capital. Para ele, o volume de negócios de um país não dependia do volume do meio circulante, mas da quantidade de capital utilizada na produção. Assim que um aumento da quantidade de moeda em circulação não faria aumentar os capitais e tampouco os negócios. Então, para que emitir notas bancárias?

Apesar de não se dizer contrário aos bancos, Rodrigues Torres mostrava pelo menos certa desconfiança quanto à sua atuação ao descrever o processo que leva uma instituição desse tipo do boom ao crash. Interessante notar

n.13, p.110, jan/jul de 2008; VILLELA, André Arruda. The political economy of money and banking in Imperial Brazil 1850-1870, p.83 e FRANCO, Afonso Arinos de Melo e PACHECO, Cláudio. História do Banco do Brasil. Brasília: Banco do Brasil, 1979, 5v., p.86.

17 Cf. BRASIL. Assembléia Geral Legislativa. Anais da Câmara dos Deputados. Rio de Janeiro, p.484. Sessão de 25 de abril de 1850 . 
como as crises financeiras, com a introdução de inovações financeiras, foram se tornando mais complexas ao longo do tempo, mas mantiveram uma fonte comum, a saber, a relação real básica entre os primeiros credores e devedores. Mas seu ponto era mesmo a valorização da moeda. Em seu discurso nada havia contra os bancos em si, mas tudo contra o momento de criá-los. ${ }^{18}$

Ficou famosa a passagem do relatório do ministério da fazenda de 1849 em que Rodrigues Torres sintetizou sua posição a respeito dos bancos e da utilização de um banco para auxiliar o governo no resgate do papel-moeda. ${ }^{19}$ Além de apontar o embaraço que os bancos emissores poderiam causar à estabilidade do valor do meio circulante, Rodrigues Torres também chamou a atenção para o fato de não haver vontade nem condições mínimas para a organização desses bancos levada a cabo pela iniciativa privada. ${ }^{20}$ Contudo, a década de 1840 assistiu ao surgimento de bancos comerciais em várias províncias. Vontade não parecia faltar aos possuidores de fundos. Mas é preciso lembrar que os discursos são muitas vezes produzidos por atores envolvidos na questão e que podem, eventualmente, manipular a informação de acordo com seus interesses. Por isso, como ensina Alfredo Almeida, ${ }^{21}$ antes de partir para a análise do que foi registrado, é necessário saber quem fez o discurso, com que finalidade tal discurso foi produzido e a que público se destinava. Por isso, não dá para desatrelar esse trecho do discurso feito para deputados pelo ministro da fazenda Rodrigues Torres de sua posição mais ampla a respeito dos bancos. A realidade era aparentemente sacrificada em nome de suas convicções. Souza Franco foi direto ao ponto quando disse que o receio do ministro em relação à criação de bancos era a desvalorização do papel-moeda do governo e que o preço a ser pago por esse receio seria o desestímulo ao crédito tanto na Corte como nas províncias. ${ }^{22}$

De fato, Rodrigues Torres considerava a estabilidade do valor da moeda e do câmbio pré-condição para o aumento da riqueza do país. Em seu relatório de 1849 , ele apontou os inconvenientes da instabilidade do valor da moeda e do câmbio e defendeu que o governo lançasse mão de todos os recursos disponíveis para estabilizar tal valor, inclusive, se o momento fosse o adequado,

18 Cf. BRASIL. Assembléia Geral Legislativa. Anais da Câmara dos Deputados. Rio de Janeiro, p.498. Sessões de 25 e 26 de abril de 1850.

19 MINISTÉRIO DA FAZENDA. Proposta e relatorio apresentados á Assembléa Geral Legislativa na Primeira Sessão da Oitava Legislatura do anno de 1849 pelo Ministro e Secretario d'Estado dos Negocios da Fazenda Joaquim José Rodrigues Torres. Rio de Janeiro: Typ. Nacional, 1850. p.36.

20 Cf. BRASIL. Assembléia Geral Legislativa. Anais da Câmara dos Deputados. Rio de Janeiro, p.99. Sessão de 8 de março de 1850 .

21 ALMEIDA, Alfredo Berno de. A ideologia da decadência: leitura antropológica a uma história da agricultura do Maranhão. São Luís: IPES, 1983.

22 Cf. BRASIL. Assembléia Geral Legislativa. Anais da Câmara dos Deputados. Rio de Janeiro: p.106. Sessão de 8 de março de 1850 . 
criar um banco que pudesse controlar a oferta de moeda. Na passagem que transcrevemos a seguir o ministro se refere à manutenção da paridade definida pela lei de 1846 como um compromisso solene entre o Estado e o país. Seria, pois, peremptória sua defesa, ainda mais por ser considerada por Rodrigues Torres um dos atos mais sensatos do legislativo brasileiro. ${ }^{23}$

No ano seguinte, Rodrigues Torres demonstrava na câmara sua preocupação com a depreciação do câmbio. Em seu diagnóstico, a instabilidade cambial indicava que o país não tinha um "sistema financeiro fundado sobre bases sérias" 24 e isso impedia o desenvolvimento da indústria e do comércio. Como visto, a essa altura ele ainda não propunha a criação de um banco de emissão para auxiliar o governo a resolver esse problema, pois, a seu ver, a conjuntura para tal não estava dada.

A posição de Souza Franco contrastava claramente com a de Rodrigues Torres, mas sua proposta de criação de bancos emissores não vinha desacompanhada do papel que caberia ao Estado em seu arranjo bancário. Para Souza Franco, os bancos deviam ser regulados pelo Estado para que não houvesse o risco de cometerem os abusos motivados pela ilusão de grandes lucros. ${ }^{25}$ Além disso, na sessão da câmara de 25 de abril, o deputado paraense dizia que quando um banco particular estivesse ligado aos interesses do Estado, como na questão do meio circulante, o governo deveria dar garantias e privilégios a essa instituição. ${ }^{26}$

$\mathrm{Na}$ proposta de Rodrigues Torres que logo se apresentaria, o banco sugerido não seria oficial, mas deveria ficar sob a tutela do Estado, que the ofereceria garantias e seria responsável pela nomeação de seu presidente e vice-presidente. Ele, inclusive, será nomeado presidente da instituição. Como vemos, as idéias relativas à criação de um banco ou bancos de emissão, que já vinham sendo apresentadas desde a liquidação do primeiro Banco do Brasil, foram fermentando no final da década de 1840 e início de 1850.

Os ventos das finanças brasileiras mudaram no início da década de 1850 e o momento adequado para a criação de um banco emissor parecia ter chegado, pelo menos para Rodrigues Torres. 0 projeto que apresentou no relatório do ministério da fazenda de 1852 previa a substituição das notas do Tesouro

23 MINISTÉRIO DA FAZENDA. Proposta e relatorio apresentados á Assembléa Geral Legislativa na Primeira Sessão da Oitava Legislatura do anno de 1849 pelo Ministro e Secretario d'Estado dos Negocios da Fazenda Joaquim José Rodrigues Torres, p.35.

24 Cf. BRASIL. Assembléia Geral Legislativa. Anais da Câmara dos Deputados. Rio de Janeiro, p.485. Sessão de 25 de abril de 1850 .

25 FRANCO, Bernardo de Souza. Os bancos do Brasil: sua história, defeitos da organização atual e reforma do sistema bancário. Brasília: Editora Universidade de Brasília, 1984, p.85.

26 Cf. BRASIL. Assembléia Geral Legislativa. Anais da Câmara dos Deputados. Rio de Janeiro, p.481-482. Sessão de 25 de abril de 1850 . 
por notas do banco conversíveis em ouro, cuja emissão poderia chegar ao triplo do lastro metálico, tal como indicara Souza Franco. Outros elementos presentes na discussão sobre o meio circulante, como a criação de um banco de resgate de notas do Tesouro e a tomada de um empréstimo junto ao banco criado para tal fim, serão notados no segundo Banco do Brasil. Por essas e outras posições, por exemplo, as defendidas nos Meios de proteger a indústria, Peláez e Suzigan consideram Rodrigues Torres um eclético quanto às questões financeiras, entre o papelista Souza Franco e o metalista Torres Homem. ${ }^{27} 0$ fato é que suas posições marcaram a política econômica levada a cabo pelo ministério da fazenda entre 1848 e 1853 , e continuaram a influenciá-la nos anos seguintes.

O fio condutor dessa política, como pareceu-nos ter ficado claro, era a estabilização do valor da moeda como condição para a montagem de uma economia civilizada, no contexto do projeto saquarema de construção do Estado imperial. A partir de 1852, ganhou força a idéia de se criar um banco com monopólio de emissão, a fim de controlar centralizadamente e ordenar a oferta monetária. A instituição ideal proposta pelos homens da moeda venceu o debate e foi concretizada em julho de 1853. O projeto saquarema seguiu em marcha com o estabelecimento do segundo Banco do Brasil. A relação entre o governo e o banco se inscreve nesse processo que se iniciará em 1853 e desde cedo enfrentará o dilema de atender às demandas do crédito ou da moeda forte, de ampliar o limite de emissão do banco ou estreitar o limite das transações comerciais no império. Entre 1857 e 1859, o projeto será interditado com a subida de Souza Franco ao ministério da fazenda. Nesse período, o império experimentaria uma reviravolta em sua política econômica, passando do monopólio à pluralidade de emissão. A origem dessa reviravolta repousava em fatores econômicos e políticos. Os primeiros ainda estão relacionados à escassez de meio circulante e de crédito nas praças para realização das transações comerciais. A demanda por maior oferta de meio circulante e crédito colocava forte pressão sobre o banco, que não conseguia irrigar as praças com liquidez suficiente para atender às necessidades da economia imperial. Os fatores políticos não foram menos importantes para explicar a reviravolta da política econômica e estavam relacionados, no fundo, à política de conciliação e à reforma eleitoral de $1855 .{ }^{28}$ Finalmente, o banco e o projeto sucumbirão entre 1864 e 1866, quando a realidade econômica do país e a guerra contra o

27 PELÁEZ, Carlos Manuel e SUZIGAN, Wilson. História monetária do Brasil: análise da política, do comportamento e das instituições monetárias. Brasília: UNB, 1981, p.76.

28 A política de conciliação procurava reincorporar o partido liberal à vida política do império depois dos episódios de 1842. Cf. CARVALHO, José Murilo. A construção da ordem, p.407; NABUCO, Joaquim. Um estadista do império. Rio de Janeiro: Topbooks, 1997, 2v, p.286. 
Paraguai obrigarão o abandono daquele que fora concebido para ser o banco da ordem conservadora.

\section{A centralização política e financeira na Corte}

Como já mencionamos, apenas três anos antes da criação do segundo Banco do Brasil, o mesmo Rodrigues Torres não se mostrava muito favorável à criação de um banco de emissão para ajudar o governo a garantir a estabilidade da moeda sem antes resgatar parte das notas do Tesouro que estava em circulação. Para ele, a essa altura, o banco só conseguiria se organizar e atrair acionistas se emitisse notas em montante superior ao que seria emprestado ao governo para que este pudesse fazer o resgate das notas do Tesouro. Desse modo, o volume do meio circulante aumentaria ao invés de diminuir. Contudo, o momento de criar um grande banco de emissão chegaria.

No início da década de 1850, foram surgindo as condições que sustentariam a ilusão saquarema de que a oferta monetária do império poderia funcionar de acordo com as regras do padrão-ouro. De 1852 para 1853, as contas do governo apresentaram superávit, o déficit comercial se reduziu e o câmbio oscilou acima da paridade de $27 \mathrm{~d}$., indicando que tal momento se aproximava. No entanto, o resultado fiscal positivo não foi acompanhado pela redução das notas do Tesouro que estavam em circulação, condição apontada por Rodrigues Torres para a criação do banco. Pelo contrário, o aumento da proporção de moeda metálica em circulação sinalizava, segundo o ministro, a necessidade de maior volume de papel-moeda em circulação para acompanhar o crescimento das transações. Era sua rendição diante da realidade da economia do país.

Entre segurar o ritmo de crescimento em função da circulação metálica e deixá-lo correr mesmo que à custa de tal circulação, um metalista não teria dúvidas em ficar com a primeira opção. Não foi o caso do pragmático Rodrigues Torres, justificando o adjetivo de eclético. 0 seu banco de emissão poderia lançar na circulação notas lastreadas em ouro ou em notas do Tesouro. De fato, o ideal metalista parecia não caber na realidade brasileira e ele parecia tentar fazer bem o serviço de adequar o ideal à realidade. Com essas justificativas, Rodrigues Torres apresentou sua proposta de criação de um banco de emissão no relatório do ministério da fazenda de 1852. A passagem do relatório em que o ministro anunciou a chegada do momento de criar um banco de emissão no país é famosa: "Parece pois chegado o prazo de criar-se um Banco de emissão, que não só auxilie o Governo no resgate do papel-moeda, mas ainda o progressivo aumento do crédito e da riqueza nacional". ${ }^{29}$

29 MINISTÉRIO DA FAZENDA. Proposta e relatorio apresentados á Assembléa Geral Legislativa na Primeira Sessão da Nona Legislatura do anno de 1852 pelo Ministro e Secretario d'Estado dos Negocios da Fazenda 
Além das justificativas apontadas pelo ministro, não se pode perder de vista que a conjuntura positiva das finanças públicas e do câmbio coincidia com o aumento da emissão de vales por parte dos bancos da praça do Rio e com o acirramento da concorrência entre esses dois estabelecimentos. Como visto há pouco, essa concorrência, que já dava as caras no ano em que foi elaborada a proposta do ministro, era percebida pelo governo como prejudicial para a economia do país e algo deveria ser feito. O senador Manuel de Assis Mascarenhas, em sessão do senado em que se discutiria o projeto de Rodrigues Torres, ponderaria que a conjuntura não mudara tanto a ponto de fazer o ministro convencer-se de que chegara o momento de criar um banco de emissão. Diria claramente que "uma das razões da apresentação do projeto é desejar o Sr. ministro, oposto como é aos bancos que existem no país, sem exceção, derrubar esses bancos". ${ }^{30}$ A proposta de criar de um banco monopólio de emissão caía realmente como uma luva nesse contexto.

Ademais, tramitava no senado desde 1850 o projeto de provincialização dos bancos de emissão de Holanda Cavalcanti, que nada mais era do que a oficialização da situação existente. Nada mais contrário aos interesses saquaremas do que a aprovação de um projeto desses, porque isso significava descentralizar o controle sobre a oferta de moeda e, por conseguinte, o poder político. Era preciso uma contra-ofensiva no campo bancário que se enquadrasse no projeto saquarema de construção do Estado imperial e ela veio em 1852.

No relatório daquele ano, Rodrigues Torres mais uma vez reconhecia os serviços que os bancos poderiam prestar à economia ao intermediar recursos entre poupadores e investidores; ao substituir parte da circulação metálica por papel, mais barato; ao agilizar, por meio das operações de desconto, o movimento de capitais e, portanto, a produção de riquezas; e, finalmente, com um toque de ecletismo, ao atuar para evitar ou neutralizar as flutuações da circulação metálica.

No entanto, tinha ele sempre um pé atrás com os bancos e para que essas instituições não viessem a perturbar a economia, deveriam seguir regras estritas, oferecer garantias concretas a suas operações e ser acompanhadas pelo Estado. Para que não viessem a ter problemas, os bancos deviam ser prudentes nas emissões, só descontar a prazos curtos e com garantias sólidas, e manter sempre em caixa um fundo disponível para restabelecer, sempre que necessário, o equilíbrio entre o movimento de notas apresentadas para troco em metal e o pagamento de letras descontadas. Esses eram os princípios de

Joaquim José Rodrigues Torres. Rio de Janeiro: Typ. Nacional, 1853, p.14.

30 O senador se refere aos bancos de emissão existentes no império, sobretudo aos da praça do Rio de Janeiro, o Banco Comercial e o Banco do Brasil de Irineu Evangelista de Souza, futuro barão de Mauá. Cf. BRASIL. Anais do Senado. Rio de Janeiro, p.152. Sessão de 28 de maio de 1853. 
uma administração bancária conservadora, bem ao gosto dos banqueiros ingleses. ${ }^{31}$ Tendo isso em conta, Rodrigues Torres propôs então a incorporação na Corte de um banco de depósitos, descontos e emissões.

Os pontos básicos do projeto revelam que Rodrigues Torres fez algumas concessões em relação à ortodoxia metalista. Longe do sonho dourado, a emissão do novo banco seria lastreada em metal ou papel-moeda, isto é, as notas do banco poderiam ser trocadas por notas do Tesouro não conversíveis ou metal. Como visto, a manutenção da paridade em $27 \mathrm{~d}$. durante alguns períodos não significava que o meio circulante estivesse totalmente lastreado em metal. 0 padrão-ouro continuava sendo uma miragem. Cedendo a Souza Franco e Paula Sousa, o projeto propunha um teto de emissão que poderia chegar ao triplo do fundo metálico do banco. Contudo, para manter o banco sob regras estritas, esse teto seria rebaixado para apenas o dobro de tal fundo. Por fim, o próprio banco seria responsável por resgatar as notas do Tesouro em circulação por meio de um empréstimo amigável que faria ao governo. Inicialmente, Rodrigues Torres sustentava que tal operação faria aumentar o meio circulante em vez de diminuí-lo, afetando negativamente seu valor, mas as circunstâncias agora eram outras e, em sua perspectiva, a economia reclamava papel-moeda.

Apesar das concessões, o ministro bateu o pé em dois pontos importantes. Primeiro, a definição da unidade de emissão de notas, cujo monopólio caberia ao novo banco, e a criação de caixas filiais emissoras com notas de circulação limitada às províncias. Segundo, o caráter privado da instituição. O banco nasceu privado, porque Rodrigues Torres estava convencido de que nenhum banco poderia ser criado pelo governo e por conta dele, lembrando-se talvez da experiência de 1833. O banco deveria agora ser alternativa de investimento interessante para os capitais privados.

A tramitação da proposta tanto no senado quanto na câmara foi rápida. De fato, os gabinetes saquarema não pareciam dar muita atenção ao parlamento. Eles entendiam que a ordem não seria resultante de uma ação política conflituosa, mas de uma ação política coordenada, subordinada evidentemente a um poder centralizado, nesse caso, a Coroa. A velocidade da tramitação da proposta de Itaboraí no parlamento pode ser vista como mais um indício do caráter apolítico das decisões daqueles gabinetes, decisões que se subordinavam menos ao parlamento e mais ao projeto saquarema de construção

31 O fundo disponível pode ser constituído por metais, papel-moeda ou títulos, e serve de base para a emissão de notas do banco. Quanto maior e mais sólido o fundo disponível, maior a garantia de troco das notas emitidas pelo banco. Para a prática conservadora dos banqueiros ingleses; Cf. GILBART, James William. Tractado practico dos bancos. Rio de Janeiro: B.L. Garnier, 1859, p.18-115; JOSLIN, David. A Century of Banking in Latin America. London: Oxford University Press, 1963, p.68. 
do Estado imperial. Para os saquaremas, de maneira geral, a prerrogativa de escolher a política a ser seguida pelo governo deveria ser do executivo e não do legislativo, justificando-se assim o certo desdém pelo parlamento apresentado pelo ministro conservador. ${ }^{32}$ Apesar das críticas à proposta, pouco menos de dois meses depois, ela se tornou a lei 683, de 5 de julho de 1853, que autorizava a incorporação do Banco do Brasil, o segundo estabelecido pelo Estado e que entrou efetivamente em funcionamento.

Eram mesmo bastante sólidas as bases apresentadas pelo ministro da fazenda na proposta que apareceu em seu relatório de 1852. A proposta foi aprovada sem emendas, passou incólume tanto no senado como na câmara, e não houve praticamente mudança em relação ao texto da proposta original. As posições de Rodrigues Torres, e por extensão do governo, prevaleceram nas duas casas, numa demonstração do poder político que colocava em marcha o projeto saquarema. Curiosamente, a solução para o que viria a ser o monopólio de emissão de notas do novo banco foi levantada apenas esporadicamente, mesmo assim de maneira acanhada. Até o momento, a fusão que logo se daria entre o Banco Comercial e o Banco do Brasil, os emissores da praça do Rio, não estava explícita nem nas discussões legislativas nem no texto da lei. Ela viria à tona pouco tempo depois.

\section{As províncias como periferias financeiras}

Como já mencionamos, a criação do segundo Banco do Brasil justificava-se, do ponto de vista econômico, pela necessidade de saneamento do meio circulante, isto é, pela necessidade de fazer valer o padrão-ouro estabelecido na reforma monetária de 1846 e garantir a conversibilidade das notas emitidas. Do ponto de vista político, a criação do banco enquadrava-se no projeto de construção do Estado levado a cabo pelos saquaremas, cujo pilar era a manutenção da ordem econômica, política e social com a centralização do poder na Corte. 0 segundo Banco do Brasil, cuja principal característica era o monopólio de emissão, viria impor o poder governamental de gestor da moeda e do crédito. A formação do Estado nacional de cunho centralizador, inserida num projeto que buscava trazer ordem e civilização ao país, não poderia prescindir do controle da moeda e do crédito. Ocorre que esse controle teria que alcançar não só a Corte, mas outras províncias do império.

Entre as décadas de 1830 de 1840, depois de um período sem bancos desde a extinção do primeiro Banco do Brasil em 1829, foram criados bancos na

32 MATTOS, Ilmar Rohloff de. O tempo saquarema, p.144; 195-196; MACHADO, Agostinho José D’Oliveira. $A$ facção saquarema. Santos: Typ. Imparcial de F.M.R. D’Almeida, 1851, p.28. 
Corte e nas províncias, todos eles emissores de vales. Os dois maiores eram o Banco Comercial e o Banco do Brasil, de Irineu Evangelista de Souza, ambos localizados na Corte. Em seguida vinham os bancos das províncias da Bahia, Pernambuco, Maranhão e Pará. Como também já mencionamos, no início da década de 1850, a conjuntura de crise que envolvia os bancos emissores da Corte abriu espaço para a proposição do monopólio da emissão de notas e, conseqüentemente, para a criação do segundo Banco do Brasil. Aprovada a proposta, expressa no projeto que dava origem ao banco, passou-se da pluralidade à centralização da emissão de notas bancárias. A emissão de vales à vista e ao portador foi proibida em todo o império e só o novo Banco do Brasil, criado em 1853, teria o direito de emissão de notas desse tipo. A questão era como fazer com que a oferta de moeda de um banco emissor que se localizava na Corte fosse capaz de atender a demanda de outras províncias, uma vez que a economia mercantil escravista contaria agora com apenas uma fonte para irrigar de notas as praças e satisfazer suas necessidades comerciais.

No Brasil, como já referimos anteriormente, a dificuldade de capilarização do meio circulante era um dos principais problemas levantados pelos opositores da centralização da emissão bancária. Como um banco localizado na Corte poderia atender à demanda de meio circulante das distantes províncias situadas ao Sul e ao Norte do império? Souza Franco, líder inconteste dessa oposição, já advertia, muito antes da criação do segundo Banco do Brasil, que as grandes distâncias e a dificuldade e demora nas comunicações eram um obstáculo que a centralização da emissão não poderia superar. ${ }^{33}$

De fato, o novo banco deveria contar com um aparato institucional para que sua emissão de alguma maneira alcançasse as praças mais distantes. A solução para o problema da circulação regional e das distâncias estava contemplada no projeto de Rodrigues Torres e passava pela criação, por parte do banco, de caixas filiais. 0 primeiro parágrafo do art. $1^{\circ}$ da lei que criou o banco previa a criação de caixas filiais onde as necessidades do comércio as exigissem. A exigência das necessidades do comércio, embora fosse um critério vago para a abertura de caixas filiais, permaneceu no art. $5^{\circ}$ do estatuto do banco. Ele aparentemente teria liberdade para abrir caixas filiais onde entendesse necessário e deveria também organizar seus estatutos, todavia, a aprovação da abertura dessas caixas teria que passar pela chancela do governo.

As caixas filiais foram assunto freqüente nas reuniões de diretoria do banco em seus primeiros anos. O ponto de partida, evidentemente, era a conversão das caixas do extinto Banco do Brasil em São Paulo e no Rio Grande do Sul em caixas filiais do novo Banco do Brasil. Iniciativa própria mesmo só a criação da caixa de Minas Gerais, em Ouro Preto, pois as outras caixas viriam

33 FRANCO, Bernardo de Souza. Os bancos do Brasil, p.83. 
da conversão dos bancos emissores existentes na Bahia, em Pernambuco, no Maranhão e no Pará. Como rezavam os estatutos da matriz, os estatutos das caixas filiais foram propostos pela diretoria do Banco do Brasil e avaliados pelo governo. Os pareceres do Conselho de Estado em todos os casos foram positivos e não contrariaram o que o banco havia afirmado. Os estatutos das caixas filiais seguiriam o padrão dos estatutos elaborados para a caixa filial de Ouro Preto. ${ }^{34}$

Se seguíssemos apenas as letras da lei e dos estatutos, seríamos levados a deduzir que a exigência das necessidades do comércio regional foi o motivo pelo qual o banco criou, com aprovação do governo, uma caixa filial na província mineira. No entanto, para além das necessidades do comércio, a caixa filial de Ouro Preto era fundamental para impedir que parte das notas emitidas pela matriz vazasse para Minas, uma vez que a demanda provincial passaria a ser atendida por notas emitidas pela própria caixa, e para atrair, via depósitos, os metais preciosos que ainda circulavam nessa província. ${ }^{35} \mathrm{~A}$ caixa de Ouro Preto, e também a de São Paulo, teria ainda a peculiaridade de receber notas emitidas pela matriz. Criava-se, assim, um espaço ampliado para a circulação das notas da matriz que abarcava as regiões próximas à Corte com as quais esta mantinha estreitos vínculos comerciais. Além disso, a caixa mineira especificamente diferenciava-se das demais por ter seu capital de 100:000\$ totalmente integralizado pelo Banco do Brasil. Talvez isso se deva justamente ao fato de não se originar de um estabelecimento preexistente, evitando assim a necessidade de negociar participação acionária com antigos proprietários. 0 capital das demais caixas, todas oriundas de estabelecimentos preexistentes, seria dividido em ações.

O parecer do Conselho de Estado em relação à caixa de Minas Gerais, datado de 16 de dezembro de 1854 e assinado por Itaboraí, Montezuma e Alves Branco, foi extremamente favorável. Enaltecia as vantagens que a caixa traria para a província e para o banco. Para a província porque contaria com um necessário estabelecimento de crédito, segundo o relatório, até aquela altura Minas Gerais não possuía ainda "no seu vasto território um só estabelecimento de crédito e falece-lhe assim um dos instrumentos indispensáveis da propriedade dos povos modernos". ${ }^{36}$ Para o banco porque a caixa movimenta-

34 Cf. BANCO DO BRASIL. Atas de reunião da diretoria (1854-1866). Sessão 121, de 28 de dezembro de 1854.

35 A atração dos metais preciosos era importante para aumentar o fundo disponível do banco e de suas caixas filiais. O fundo disponível, reserva em moeda corrente e ouro, era a base sobre a qual os bancos emitiam. Para a questão da criação da caixa filial de Ouro Preto. Cf. LEVY, Maria Bárbara e ANDRADE, Ana Maria Ribeiro de. Fundamentos do sistema bancário no Brasil, p.38.

36 BRASIL. Imperiaes resoluções do Conselho de Estado na secção de fazenda desde o anno em que começou a funccionar o mesmo Conselho até o presente. Rio de Janeiro: Typ. Nacional, 1870, p. 355. 
ria, por meio dos descontos, capitais que, de outro modo, ficariam dormentes em seus cofres sem the render os frutos oriundos das operações financeiras. Da mesma maneira, o parecer do Conselho de Estado sobre a caixa de São Paulo, assinado em 17 de março de 1855 por Itaboraí e pelos agora viscondes de Jequitinhonha e Caravelas, acatou todas as reivindicações do banco. Tendo em vista que a caixa de São Paulo seria resultado da conversão da caixa filial do extinto Banco do Brasil, o parecer foi favorável inclusive à possibilidade de que, nos primeiros tempos, a caixa descontasse títulos com prazos mais longos, entre quatro e seis meses. Nesse mesmo dia, também saiu o parecer favorável à conversão dos bancos emissores das províncias e da caixa filial do Rio Grande do Sul em caixas filiais do novo Banco do Brasil. Num parecer bastante sucinto, os mesmos conselheiros recomendam a aprovação dos estatutos das instituições financeiras que espraiariam a orientação financeira saquarema pelas províncias do império.

Apesar de terem os estatutos aprovados rapidamente pelo governo, as caixas filiais não entrariam em funcionamento imediatamente. Pelo contrário, ainda demorariam muito a estender o benefício do crédito do Banco do Brasil às províncias. Como vimos, os decretos que autorizavam o funcionamento da caixa de Ouro Preto e das demais caixas eram de dezembro de 1854 e março de 1855, respectivamente. As caixas de Ouro Preto e São Paulo, primeiras a entrar em operação, só iniciaram suas atividades em janeiro de 1856. Em março do mesmo ano, entrou em operação a caixa do Rio Grande do Sul. Em julho, foi a vez das caixas da Bahia, Pernambuco e Maranhão. No mês seguinte, finalmente abriu suas portas ao público a caixa do Pará. Passou-se mais de um ano entre a aprovação dos estatutos e o efetivo funcionamento das caixas. O que houve? O relatório do Banco do Brasil de 1856 aponta a preparação e assinatura das notas para emissão como causa principal do atraso, aliás, mesmo motivo alegado para justificar o atraso no início das operações da matriz.

Fosse ou não fosse essa a principal causa do atraso, o fato é que, nesse ínterim, a fragilidade do fundo disponível se revelava o calcanhar de Aquiles da matriz e the trazia problemas para se manter dentro do limite de emissão. Como vimos, o banco padecia com a sangria de seu fundo disponível causada pela saída de recursos para as províncias do nordeste. Tanto o banco como o governo acompanhavam a situação como preocupação. As remessas de metais e papel-moeda para as províncias do nordeste eram sempre apontadas, pelo banco e pelo governo, como causa da fragilidade do fundo disponível da instituição. Para o banco, a solução do problema não passava 
apenas pelas operações das caixas, mas pelo equilíbrio da balança comercial interprovincial ou pela administração da taxa de desconto. Em que pese a questão da provincialização da circulação das notas emitidas pelas caixas, como observaram Cavalcanti, Levy e Andrade, e Vieira, para o governo, o estabelecimento de caixas filiais seria a solução para conter a fuga de recursos enfrentada pelo banco ao longo de seus primeiros anos. ${ }^{37}$ A circulação das notas emitidas pelas caixas, ainda que limitadas às respectivas províncias, aliviaria em boa medida o problema. Assim, o governo pressionava e criticava a administração do banco pelo atraso do início das operações das caixas filiais. Afinal, com estatutos aprovados há mais de um ano, já era tempo de iniciar suas atividades.

0 auge da pressão governamental para que as caixas filiais entrassem em funcionamento se deu com o rompimento do limite de emissão a que nos referimos anteriormente. Embora Itaboraí, então presidente da instituição, dissesse que as caixas não seriam solução para o problema da fragilidade do fundo disponível do banco, Paraná, então ministro da fazenda, insistia que as caixas ajudariam a conter a saída de recursos e reclamava do atraso do início das operações das caixas, ainda mais tendo em vista que os estatutos da caixa de Ouro Preto já estavam aprovados desde 1854 e os das demais caixas desde 1855. A pressão governamental surtiu efeito e, finalmente, as caixas entraram em operação ao longo de 1856. Mas o tempo deu razão a Itaboraí e mesmo depois que as caixas entraram em operação, a fragilidade do fundo disponível do banco continuou. Tanto que o limite de emissão, alargado temporariamente em abril de 1855, teve que ser mantido pelo governo em fevereiro de 1856, num decreto assinado pelo próprio Paraná.

Apesar dos diagnósticos divergentes, a criação das caixas filiais era interessante para o banco e para o governo. Nada melhor do que as palavras de Itaboraí, ao mesmo tempo representante da instituição e encarnação do projeto político do governo, em seu relatório de 1856, apresentado aos acionistas do banco, para indicar o interesse comum: "cumprindo-nos procurar difundir o crédito por todos os pontos mais importantes do Império, algum sacrifício que seja preciso fazermos para tal fim não nos deve empecer no desempenho desta missão civilizadora". ${ }^{38}$ Era a difusão do crédito e a missão

37 CAVAlCANTI, Amaro. O meio circulante nacional (1836-1866). Rio de Janeiro: Imprensa Nacional, 1893; LEVY, Maria Bárbara e ANDRADE, Ana Maria Ribeiro de. Fundamentos do sistema bancário no Brasil; e VIEIRA, Dorival Teixeira. Evolução do sistema monetário brasileiro. São Paulo: IPE/USP, 1981.

38 BANCO DO BRASIL. Relatório apresentado á Assembléa Geral dos Accionistas do Banco do Brasil na sua reunião de 1856, pelo seu Presidente Visconde de Itaborahy. Rio de Janeiro: Typ. Nacional, 1856, p.10. 
civilizadora, no limite, representada pela moeda, que uniam os interesses do banco e do governo.

Embora o volume das operações das sete caixas filiais nunca tenha ultrapassado o da matriz, elas cumpriram, pelo menos em parte, o desígnio de levar a moeda e o crédito às províncias e contribuíram para aumentar as operações do banco (Gráfico 1).

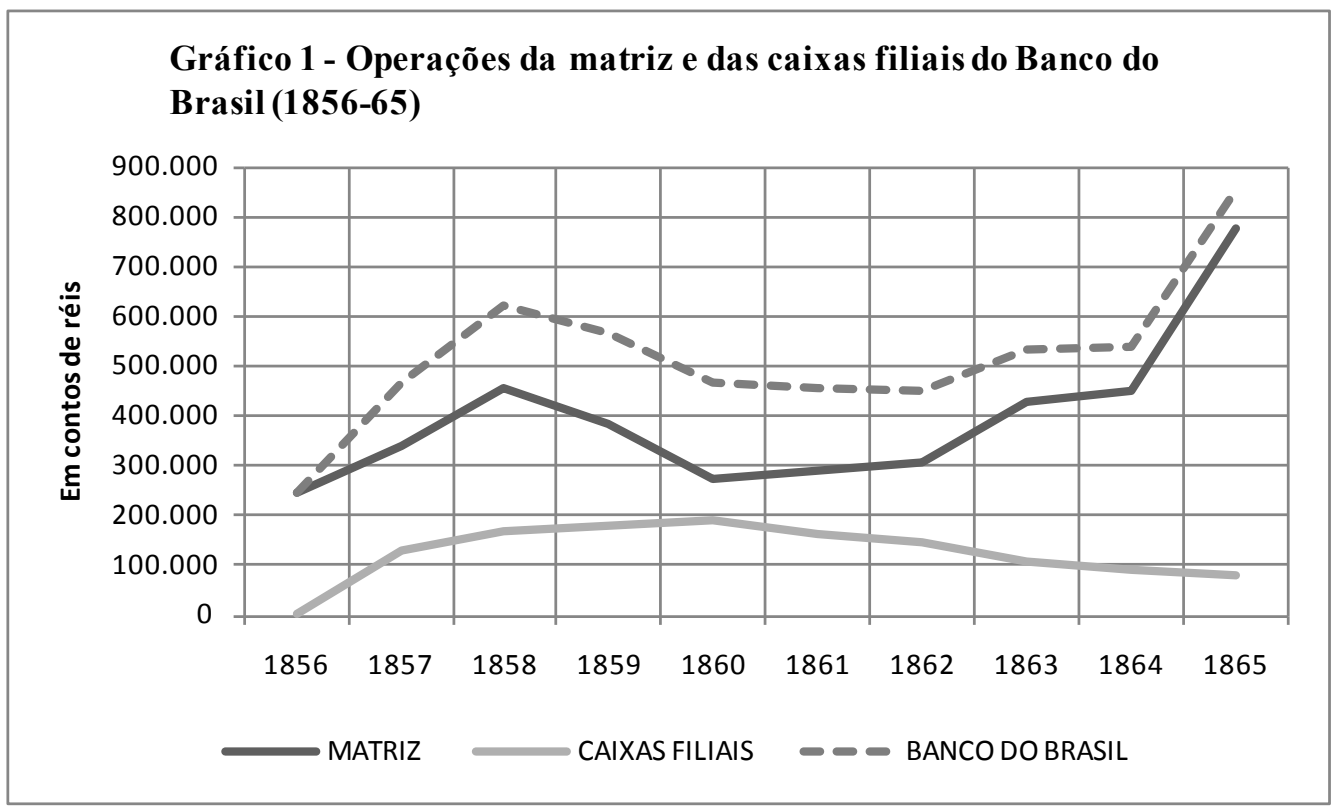

Fonte: Relatórios do Banco do Brasil (1856-1865).

Se por um lado a criação das caixas faria aumentar as operações e, portanto, o lucro do banco como um todo, por outro, ajudaria o governo a capilarizar a oferta de crédito pelas províncias do império e atenuar o problema da escassez de meio circulante e de crédito que embaraçava as transações comerciais. Vale lembrar que tal oferta sempre esteve condicionada ao limite das emissões, que correspondia ao triplo do fundo disponível de cada caixa. Os interesses do banco e do governo caminhavam juntos nesse caso, o risco era de que a administração das caixas fugisse ao controle da matriz e, por extensão, do próprio governo. Para que isso não ocorresse, os diretores das caixas foram escolhidos a dedo e, de fato, até o fim do monopólio de emissão, em 1866, as caixas permaneceriam sob controle da matriz e da política econômica do governo. 


\section{A dinâmica centro e periferia}

A dinâmica das caixas filiais do Banco do Brasil e de suas relações com a matriz abre espaço para uma breve discussão do desenvolvimento financeiro no centro e na periferia do império que, por sua vez, acabará nos conduzindo ao projeto saquarema de construção do Estado. Entre 1854 e 1866, o Banco do Brasil era de longe o maior banco do império. De acordo com dados de Peláez e Suzigan, nesse período, ele absorvia aproximadamente $31 \%$ dos depósitos bancários totais e ficava com $62 \%$ do total de encaixes. ${ }^{39}$ Portanto, falar do banco e de suas filiais corresponde, em boa medida, a falar das instituições financeiras do império como um todo. 0 relativo controle da matriz sobre as filiais caracterizaria uma relação entre metrópole e hinterlândia, tal como definida por Cameron? ${ }^{40}$

Para responder a essa questão, é preciso retomar as caracterizações de metrópole e hinterlândia deste autor. A metrópole seria, evidentemente, adiantada do ponto de vista financeiro. Seu interesse em relação à hinterlândia seria manter por lá a estabilidade econômica, política e social por meio da influência ou do controle sobre as atividades financeiras desse espaço. Essa influência ou esse controle assumiriam a forma de regulamentação ou propriedade das instituições financeiras da hinterlândia e de imposição de uma política econômica ortodoxa. Ora, diante do que vimos anteriormente, podemos dizer que, no caso em tela, embora a propriedade das instituições financeiras da hinterlândia estivesse nas mãos de agentes econômicos e políticos locais, a metrópole não só regulamentava fortemente as atividades dessas instituições, como impunha sua política econômica de cunho restritivo. Contudo, não se tratava de adotar uma política restritiva na hinterlândia e expansionista na metrópole tendo em vista o desenvolvimento de uma e o atraso relativo da outra e da manutenção dos poderes econômico, político e social que isso acarretava. Tratava-se aqui de espalhar a boa política econômica, a ortodoxa, a todo espaço econômico do império, seja na metrópole, seja na hinterlândia. Apesar da forte pressão da demanda por crédito típica de uma economia mercantil e escravista como a brasileira na época, o privilégio da moeda se fazia sentir em todas as praças por meio da política restritiva proposta no projeto saquarema. Contudo, o comportamento das emissões da matriz e das caixas

39 PELÁEZ, Carlos Manuel e SUZIGAN, Wilson. História monetária do Brasil.

40 CAMERON, Rondo. Metrópole e hinterlândia na história das finanças. Revista Brasileira de Economia, v.26, n.3, p. 237-254, jul-set.1972. 
filiais revela uma política apenas de fundo restritivo, isto é, o volume de emissão aumenta com o tempo, mas o limite de emissão definido pelo governo não chega a ser rompido definitivamente até 1864 (Gráfico 2).

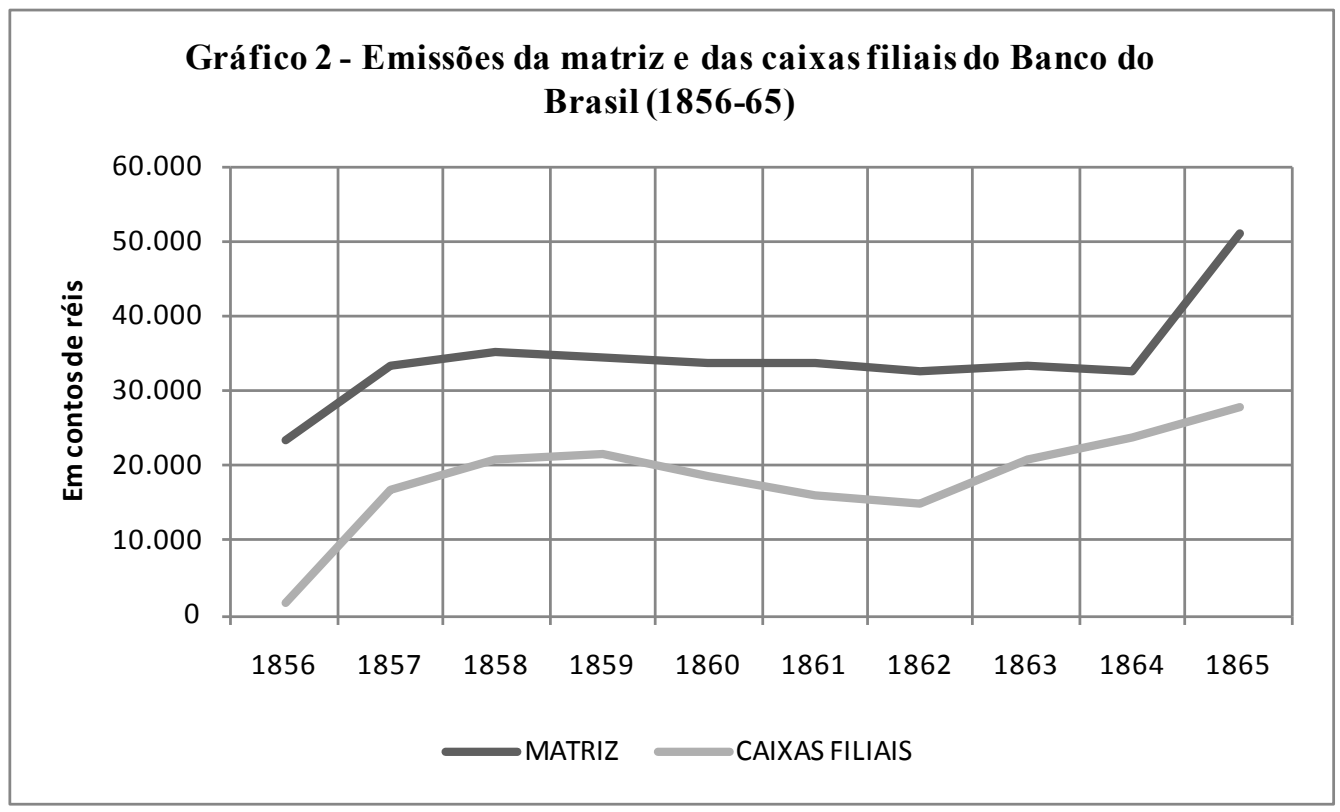

Fonte: Relatórios do Banco do Brasil (1856-65).

Vale lembrar aqui que, apesar da tendência de crescimento acelerado das emissões, o Banco do Brasil procuraria manter-se dentro dos limites de emissão estabelecidos pelo governo. 0 aumento das emissões poderia até dar a impressão de uma política expansionista por parte do governo e de uma administração frouxa por parte do banco. No entanto, essa expansão encontrava um limite claramente definido pelo governo dado por sua política econômica restritiva. 0 privilégio era da moeda, mas o crédito poderia, e deveria, diante da demanda da economia mercantil e escravista, ocupar seu espaço até esse limite. Nesse sentido, o banco e suas caixas filiais se enquadravam no projeto saquarema. Vale lembrar ainda que essa era uma política econômica ortodoxa peculiar, isto é, perseguia o padrão-ouro como rezava a cartilha européia da boa política econômica, mas o fazia acomodando esse objetivo às condições da economia brasileira, o que pode ser verificado, por exemplo, na inusitada possibilidade de lastrear notas do banco em notas emitidas pelo governo. Os dirigentes saquaremas se inspiravam na ordem e civilização dos países europeus, mas, a julgar pelas adaptações que faziam em suas políticas, sabiam que a implantação da ordem e civilização nos trópicos teria que seguir um 
caminho particular. Assim, era a política econômica ortodoxa peculiar que emanava da metrópole financeira e se espalhava pela hinterlândia.

Ainda de acordo com Cameron, a influência ou controle da metrópole sobre a hinterlândia poderia seguir fins particulares, políticos ou públicos. Os fins particulares estariam ligados à busca de lucros por parte de instituições financeiras da metrópole; os fins políticos diriam respeito aos benefícios que os dirigentes da metrópole poderiam obter para si e seus apaniguados a partir da influência ou controle da hinterlândia; e, finalmente, os fins públicos se relacionariam a uma intenção honesta por parte dos dirigentes da metrópole de orientar as instituições financeiras da hinterlândia para o que presumiriam ser o mais adequado para elas e para o país. Como veremos ao longo do texto, no caso do Banco do Brasil, predominavam os fins públicos, no sentido de que a metrópole orientava a atuação das instituições financeiras da hinterlândia rumo a uma política considerada a mais adequada para elas e para o país, a política econômica saquarema. Isso não nega que a metrópole possa ter lançado mão de expedientes para aumentar o lucro da instituição ou para favorecer tal ou qual grupo de interesse. 0 projeto saquarema de construção do Estado predominava sobre fins particulares ou da pequena política. Ligado a um fim político era evidente que estava, mas a um fim da grande política, por assim dizer, pois vislumbrava, para além dos interesses partidários, um futuro de ordem e civilização para todo o império. Como comentamos, confundir os interesses do partido conservador com os do império como um todo foi uma tacada política dos dirigentes saquaremas. ${ }^{41}$

Se havia metrópole, havia hinterlândia e ela se caracterizava por ser atrasada do ponto de vista financeiro. Contudo, segundo Cameron, a hinterlândia lutaria contra o jugo metropolitano para que pudesse desenvolver seu setor financeiro, procurando caminhos alternativos para se libertar da política econômica ortodoxa imposta pela metrópole. Era como se o objetivo metropolitano de estabilização do valor da moeda acorrentasse a oferta de crédito e, por conseguinte, o desenvolvimento econômico da hinterlândia. Elas lutariam, portanto, para romper os grilhões da moeda, ampliar sua oferta de crédito e liberar seu desenvolvimento econômico. No caso do Banco do Brasil, no período analisado, o jugo metropolitano era claro, mas a rebeldia das províncias não ultrapassava os limites de administrações por vezes frouxas que, ora aqui ora ali, procuravam ampliar seus lucros particulares. Embora a oferta de crédito das caixas filiais fosse sempre inferior a da matriz,

41 MATTOS, Ilmar Rohloff de. O tempo saquarema, p.179; CARVALHO, José Murilo. A construção da ordem, p.249-260. 
entre 1856 e 1859, essa oferta foi crescente tanto na matriz como nas caixas filiais. A partir de 1860, o movimento se descolou. A oferta de crédito passou a cair constantemente nas caixas filiais a aumentar na matriz (Gráfico 3).

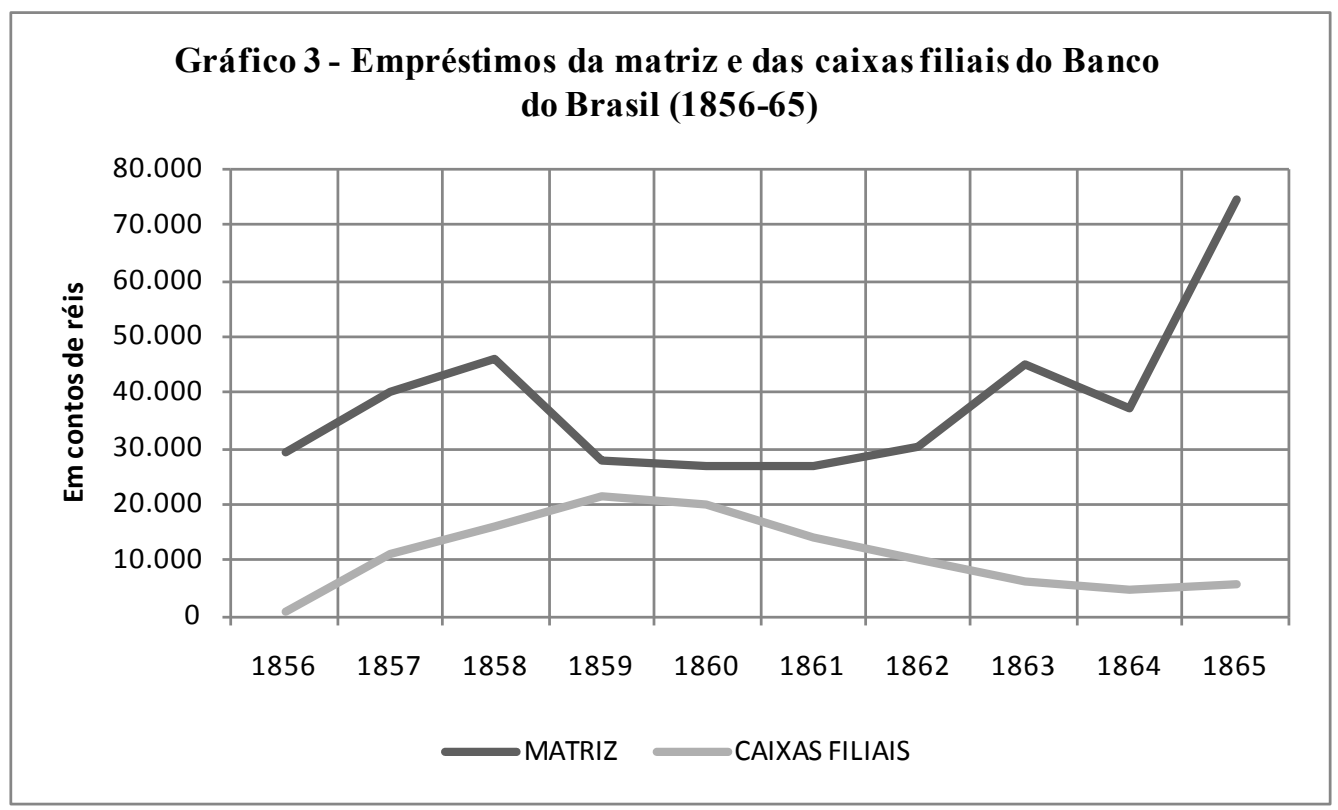

Fonte: Relatórios do Banco do Brasil (1856-65).

O descolamento da oferta de crédito da matriz e das caixas filiais poderia indicar uma política expansionista na metrópole e restritiva na hinterlândia. No entanto, não era esse o caso. 0 governo promulgou, em 1860, a famosa lei dos entraves, que estabelecia uma política econômica restritiva. Assim, a oferta de crédito na metrópole aumentou, apesar da política restritiva e não por conta de uma política expansionista que tivesse esse fim. Por aqui a moeda prevaleceria sobre o crédito também na hinterlândia. Sem muita rebeldia. A política saquarema preparou o terreno para que seu projeto econômico penetrasse nas províncias sem maiores desgastes.

Vale ressaltar que a idéia de hinterlândia não é estática. Suas instituições financeiras poderiam muito bem se desenvolver e, na medida desse desenvolvimento, produzir suas próprias políticas financeiras, atuando como a metrópole. A implicação desse movimento é que a política econômica expansionista, que caracterizaria a hinterlândia, tenderia a ficar cada vez mais restritiva, característica da metrópole financeira. Portanto, se a política financeira da metrópole privilegia a moeda e a da hinterlândia privilegia o crédito, teríamos, de acordo com esse esquema, o privilégio dinâmico da moeda sobre o 
crédito. É como se inicialmente o crédito prevalecesse na hinterlândia até que sua economia e, por extensão, suas instituições financeiras, se desenvolvessem e, a partir desse desenvolvimento, passasse a prevalecer a moeda e a estabilidade econômica, política e social. Portanto, tal esquema reforçaria o caráter conservador da metrópole financeira. Como nosso período de análise é relativamente curto, essa dinâmica não pôde ser observada. No entanto, a experiência da pluralidade de emissão de 1857 levou à criação de bancos cujo objetivo mais geral era atender à demanda por crédito nas províncias. ${ }^{42}$ Embora nesse período a política econômica tivesse se tornado expansionista, ela continuava a emanar da metrópole e esta continuava a influenciar ou controlar as instituições financeiras da hinterlândia.

\section{Considerações finais}

No fundo, mais do que uma relação de dominação entre metrópole e hinterlândia, as diferentes políticas econômicas executadas no período em questão revelavam o conflito entre Corte e províncias. Do ponto de vista da política econômica, esse conflito se expressava no duelo político entre metalistas e papelistas. Como já apontamos, embora a relação entre poder descentralizado e papelismo seja estreita, não é possível associar sem mais frações da classe dominante provinciais às idéias papelistas. A unidade de emissão, isto é, a centralização do poder na Corte, era defendida por grupos ligados ao comércio externo e por proprietários de terra escravistas não só do centro-sul como também das províncias do Norte. A pluralidade de emissão era sustentada por grupos mais ligados ao comércio interno. ${ }^{43}$ Contudo, seja com monopólio ou pluralidade de emissão, o pequeno número de bancos criados, a proibição de bancos de emissão, as regras estritas de emissão e o fato das operações de sete caixas filiais nunca ultrapassarem as da matriz marcaram a atrofia do setor financeiro brasileiro.

Finalmente, nesse período, encontramos características na relação entre Corte e províncias que a aproximam da relação entre metrópole financeira e hinterlândia. Entretanto, essa era uma relação com características um pouco diferentes do que seria o padrão dessa relação. Em primeiro lugar, tanto na metrópole como na hinterlândia havia praticamente uma instituição financeira, o Banco do Brasil. Ademais, essa era uma instituição privada, apesar

42 A partir de 1857, o monopólio de emissão do Banco do Brasil foi quebrado. Foram criados então cinco novos bancos emissores e um banco de depósitos e descontos já existente também passou a emitir notas. Depois da lei dos entraves, de 1860, um desses bancos foi incorporado ao Banco do Brasil, outro vendeu seu direito de emissão ao mesmo banco e os outros quatro deixaram de emitir diante das novas regras restritivas impostas pelo governo.

43 GUIMARÃES, Carlos Gabriel. Bancos, economia e poder no segundo reinado. 
de fortemente influenciada pelo governo. É verdade que as filiais do banco tinham diretorias próprias e eram responsáveis pela distribuição do crédito nas províncias. Contudo, gozavam de autonomia apenas relativa, pois esbarravam na regulamentação imposta pela metrópole financeira. Como bancos emissores, eram responsáveis também pelo controle da oferta de moeda e, por isso, tinham que obedecê-la. Segundo, diferentemente do padrão, a política econômica da metrópole não se diferenciava da política econômica da hinterlândia. A hinterlândia seguia a mesma política da metrópole financeira, fosse ela expansionista ou restritiva, e não esboçava reação significativa diante da investida da metrópole. Isso não é surpreendente no caso da política econômica expansionista, todavia, no caso da política econômica restritiva essa passividade podia indicar o grau de adesão das províncias à política econômica conservadora. Assim, o projeto saquarema lançava-se para além da Corte, espraiando a Ordem pelo império. 